\title{
Estate Planning: Your Will ${ }^{1}$
}

\author{
Josephine Turner ${ }^{2}$
}

Even though there are many estate-planning tools, a will is considered to be the cornerstone of most estate plans. A will is a written legal document that takes effect at death. It is used to administer the estate, including transferring property ownership and making provisions for the care of minor or dependent children.

States differ on the requirements of a valid will. For instance some states require two witnesses and some states require three. The state in which you reside-your domicile-will determine the validity of your will.

A properly drawn will simplifies the administration of an estate, minimizes costs, and minimizes family conflict over property distribution. Your estate is everything you own. It includes your home, automobile, jewelry, bank accounts, investments, retirement plans, furnishings and other belongings. Your estate will include probate and non-probate property. Non-probate property is distributed according to deed, title, or contract. Probate property is distributed according to your will, or if there is no will according to state law.

At your death, the non-probate property that you own will go directly to person(s) indicated in a deed, title, or contract that you have prepared during your lifetime. This property does not go through probate, the court procedure used to change title to property. You cannot transfer this property by a will.
Examples of non-probate property include:

- Real estate that you and your spouse own as "tenants by the entirety." At the death of one owner, the property goes to the surviving spouse

- Property you own with one or more persons jointly with "rights of survivorship".

- Bank accounts that say the account is payable to "either or the survivor."

- Insurance policies payable to a named beneficiary.

- Property in a trust is non-probate if the trust agreement indicates how the trust property is to pass at the death of the trustor.

Probate property is all the property that you own that does not, by the way it is titled, have survivorship rights.

Examples are:

- Property you own as tenants in common.

- Property you own by yourself-sole ownership.

Probate property is the property that is transferred by your will, or if there is no will by state law.

1. This document is FCS5241, one of a series of the Department of Family, Youth and Community Sciences, Florida Cooperative Extension Service, IFAS, University of Florida. Publication : December 2002. Reviewed by: Mary N. Harrison, professor of Consumer Education, FYCS; Gary E. Pleiss, FCS agent, Pinellas County Extension; Dena K. Wise, associate professor and Family Economic specialist University of Tennessee. Please visit the EDIS Web site at http://edis.ifas.ufl.edu

2. Josephine Turner, CFP, Ph.D., professor of Family and Consumer Economics, Department of Family, Youth and Community Sciences, Cooperative Extension Service, IFAS, University of Florida, Gainesville, 32611. 


\section{Preparing Your Will}

It is advisable to have an attorney competent in developing and executing estate plans prepare your will. The Florida Bar certifies attorneys for five years in Wills, Trusts and Estates, upon completion of an application, a rigorous written exam, and satisfactory professional ethics record. Even though not all good attorneys are board certified you can be assured that a Bar-certified attorney has a good reputation and a proven level of expertise.

For your will to be valid in the state of Florida:

- The testator (person writing the will) must be at least 18 years of age or an emancipated minor.

- The testator must be of sound mind at the time the will was signed (that is he/she knew what he/she was doing, i.e. making his/her will, what property was owned, and who the relatives and potential heirs were.)

- The will must be in writing.

- The will must be signed and dated in the presence of at least two witnesses.

- The two witnesses must sign in the presence of each other and the testator.

You can minimize attorney fees by preparing the following information and providing it to the attorney:

- $\quad$ List your goals and objectives for your family and your business.

- List of your family members, names, addresses, ages, and Social Security Numbers.

- List of people to be included in your will. (If you are eliminating a family member from your will, give reasons why.)

- The financial condition of your estate.

a. Provide a net worth statement (Identify all property both probate and non-non probate
[Include the value of the property and

indebtedness against the property.])

b. Your own personal desires (who you want to inherit and what you want each person to receive.)

- If you have minor children, who do you want to be the children's guardian?

- Ideas about the management of property being left to a minor child.

- Ideas about the financial needs of those people for whom you are responsible.

- Your personal representative and a contingent personal representative (person who administers your estate at your death). Some states call this person an executor or executrix.

Once you have made your will, be sure to sign it and keep it up to date. Review on a regular basis and change as law changes or family and financial situation changes.

\section{Last but not least: Self-proving wills}

After you have written your will you may notice that you are required to sign twice. Your attorney is trying to make things easier for you. The first signature indicates that you are the person making the will and your signature is evidence that this will expresses your wishes. The second time you sign, you are signing a provision that makes the will self-proving. A self-proving will can be admitted to probate without further evidence that it is eligible to be probated. No witnesses are required to offer testimony.

Sign only one copy of your will. You may want to have extra-unsigned copies of your will available to you so that it can be reviewed periodically.

\section{Where to Keep Your Will}

A secure place to store your will is in a safe deposit box. In the past, some authorities advised against this because of the difficulty of gaining access to the box after death of the owner. This difficulty has been 
substantially ameliorated under current Florida law. Some people may prefer to leave their will with their attorney or to store it in a locked file cabinet or safe at home. The important thing is to store your will where it is easy for someone to locate when you die and where it will not be lost or accidentally destroyed.

Periodically review your will to ensure that it reflects your wishes. Review your will whenever your family situation change-such as marriage, divorce, death of family members, birth or adoption of children, children reaching adulthood, or substantial change in the value of your estate.

You may change your will anytime before your death, but you must follow correct procedures. Never change it by crossing out portions on the original document. In some cases you may change your will by adding a codicil. A codicil allows a person to modify provisions in his or her will without drafting an entirely new will. In other cases, you might need to write a new will.

You may revoke your will any time before death. It is revoked when you destroy the will with the intent to revoke it. It may also be revoked by executing a new will that expressly revokes any prior will.

\section{Disclaimer}

This publication is not intended to be a substitute for legal advice. Rather, it is designed to create an awareness of the need for estate planning and to help families become better acquainted with some of the devices involved. Further changes in laws cannot be predicted, and statements in this publication are based solely upon the laws in force on the date of publication.

\section{Acknowledgment}

Many thanks to Mr. Richard M. White, Jr., Florida Bar Certified in Wills, Trusts and Estates, Gainesville, Florida, for reviewing this publication for accuracy.

\section{Reference}

Berteau, John T. 1998. Estate Planning in Florida $2^{\text {nd }}$ Edition. Sarasota, Florida: Pineapple Press, Inc.

Garman, E. Thomas and Forgue, Raymond E. 2000. Personal Finance $6^{\text {th }}$ Edition. New York: Houghton Mifflin Co..

Pohl, Esq., Amelia E. 1999. When Someone Dies in Florida. Boca Raton, Florida: Eagle Publishing Co.

Chapter 732 and 733 State Statues

http://www.leg.state.fl.us/Statues/ 